\title{
https://doi.org/10.46813/2020-130-204 \\ EXCITATION TEMPERATURES IN PLASMA OF UNDERWATER DISHARGES BETWEEN IRON GRANULES
}

\author{
A. Murmantsev, A. Veklich, V. Boretskij \\ Taras Shevchenko National University of Kyiv, Kyiv, Ukraine \\ E-mail: murmantsev.aleksandr@gmail.com
}

\begin{abstract}
This paper deals with development of optical emission spectroscopy techniques for diagnostic of underwater discharge plasma between iron granules. The difficulties in selection of iron spectral lines, as well as the approximation of their profiles for determination of excitation temperature are discussed. A method of spectral lines resolving with close wavelengths is considered. Simulation of a narrow rangeof the plasma emission spectrum is carried out to estimate the excitation temperatures in underwater discharge plasma.
\end{abstract}

PACS: 52.70.-m, 52.80. Wq

\section{INTRODUCTION}

Nowadays, there is an increasing interest in the underwater discharges (particularly, plasma of such discharges). First of all, this is duetoits numerous practical applications in biology, chemistry and electrochemistry etc. Also, the interest is reinforced due to the need to clarify physical processes of current flow in such environment.

The application of electrical discharges in liquids has to be one of the most modern and accessible methods not only for water purification (removal of organic compounds), but also surface treatment and plasma sterilization (disinfection or extermination of microorganisms) [1-3]. It is due to low efficiency of existing traditional methods and the presence of a number of the shortcomings of other methods that are still being developed (e.g. chlorination, ozonation, advanced oxidation processes, photocatalysis) [4-6]. Due to consequence of electric breakdown in water such discharges are simultaneously effective sources of intense UV radiation, shock waves and various chemical products, including $\mathrm{OH}, \mathrm{O}, \mathrm{HO}_{2}, \mathrm{H}_{2} \mathrm{O}_{2}$ [7, 8]. In addition, the shock waves, generated by high-energy underwater discharge plasma, are used for various applications, such as: underwater explosions [9], the fragmentation of the rocks [10] and lithotripsy [8].

The synthesis of nanomaterials through plasmaliquid interaction, including configurations, "plasma over liquid" and "plasma in liquid" [11] is another important application of underwater electrical discharges, which attracts considerable attention. It is found that colloidal solutions with nanoparticles are the most suitable form for biological usage [12]. It is known that the solutions of nanoparticles of different metal (particularly iron) have excellent bactericidal, antiviral, antifungal and antiseptic effects [13], which makeit essential biocide products.

Considering the abovementioned, the main aim of this work is development of investigation techniques of underwater discharge plasma between iron granules, specifically determination of one of thekey plasma parameter of such discharge - excitation temperature.

\section{EXPERIMENT}

The investigation of underwater discharge plasma between iron granules is carried out directly in the discharge chamber of the installation, specially developed for the synthesis of colloidal substance with metal nanoparticles (Fig. 1).

The discharges are ignited by pulses of the generator, which is powered by a single-phase voltage $220 \mathrm{~V}$, between iron granules, immersed into waterinside the chamber. The composition of power diodes VD1 and VD2, thyristors VD3 and VD4 and capacity $\mathrm{C} 1$ (adjustable from 25 to $650 \mu \mathrm{F}$ ) is used as a controlled phase rectifier. Randomly switching of microdischarges between various pairs of granules is realized due to pulse voltage in output of thyristor VD5. Registration of electrical parameters can be performed by the voltage divider, Rogowski coil and oscilloscope.

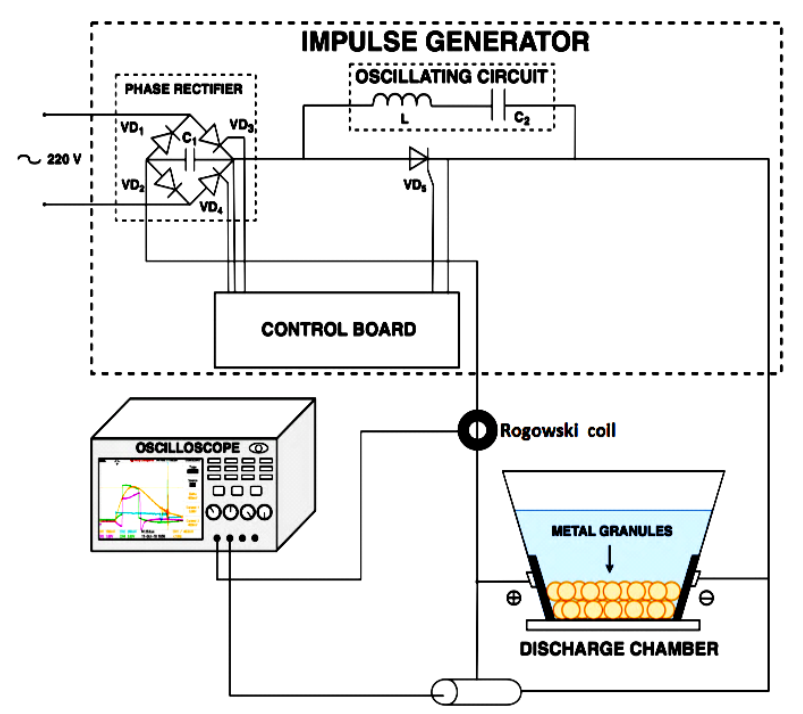

Fig. 1. Experimental arrangement for pulse underwater electrical discharge investigation [14]

The granules, immersed intoa deionized water, are moving during the discharges, which leads to the changing of discharges position in the volume of the chamber. The observation and registration of radiation were allowed by quartz window, which was installed into the wall of the discharge chamber. Under these ISSN 1562-6016. BAHT. 2020. №6(130) 
conditions, it is not possible to fix the locations of discharges, so the spectral device was placed in front of the window in the mode of continuous registration. It was possible to successful register the radiation of moving discharges when it fell into the area in front of the window.

The registration of emission spectra of underwater discharge plasma at current pulse up to $150 \mathrm{~A}$ is provided by Solar LSSDH-IV spectrometer in the spectral range from 440 to $910 \mathrm{~nm}$. The spectral sensitivity of such device is determined by tungsten band-lamp and is taken into account during spectroscopy treatment.

\section{RESULTS AND DISCUSSIONS}

Typical emission spectra of underwater discharge between iron granules are shown in Fig. 2. The emission spectrum consists predominately of $\mathrm{Fe} \mathrm{I}$ with $\mathrm{H}_{\alpha}$ and few O I spectral lines. Such set of spectral lines is sufficient for excitation temperature estimation using Boltzmann plot on the base of Fe I lines.

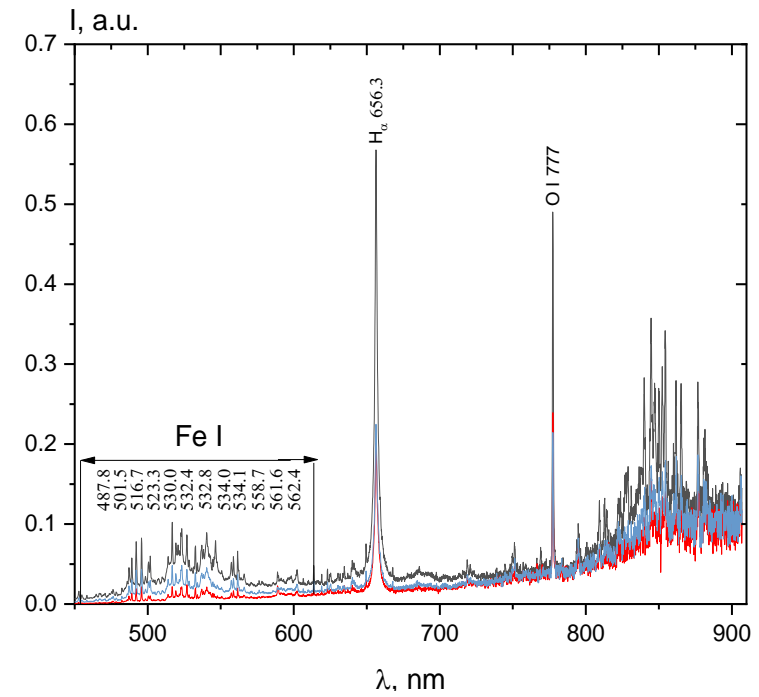

Fig. 2. Plasma emission spectra of underwater discharge between iron granules

It is well-known, the spectral lines profiles of metals, broadened by Stark effect, have the shape of Lorentz function [15]. In the frame of this work, the Voigt fitting function is used. Such approach allows to obtain the spectral line emission intensity, as well as to perform a deconvolution of contribution of the spectrometer instrumental function, which have shape of Gaussian.

The examples of Voigt profile fitting of several enough isolated spectral lines are shown in Fig. 3. There are two unsolved problems in such fittings. One of them is the influence of continuum emission (see Fig. 3,a), which can lead to overestimation or underestimation of the line intensity. Another problem deals with impact of a significant amount of lines with low intensity (see Figs. 3, b).

The plasma emission spectra of underwater discharge between iron granules is very complicated due to systematic overlaping of Fe I spectral lines contours (Fig. 4). Only three Fe I spectral lines (516.7, 558.7, and $561.6 \mathrm{~nm}$ ) were found to be enough separated.
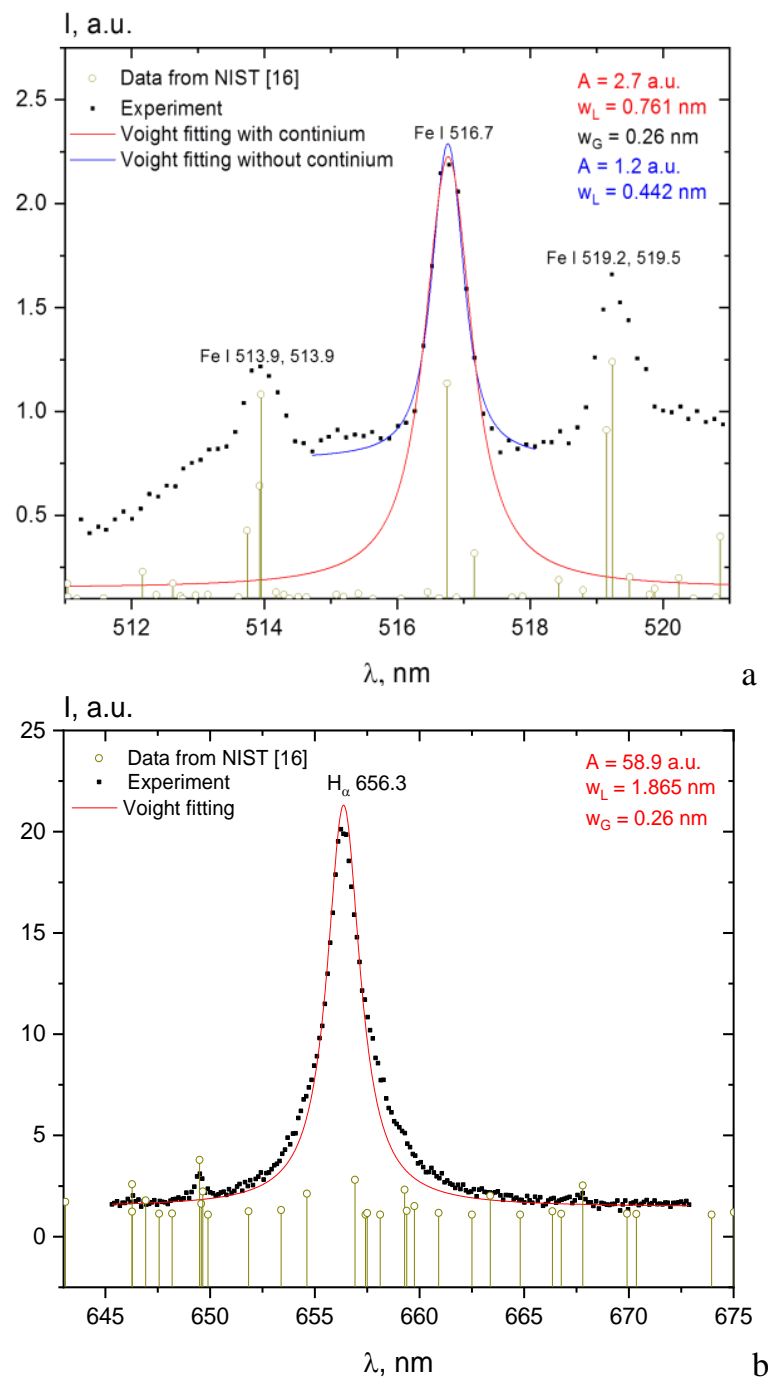

Fig. 3. Typicalline profiles and Voight fitting of Fe I (a) and $H_{\alpha}(b)$ spectral lines in underwater discharge

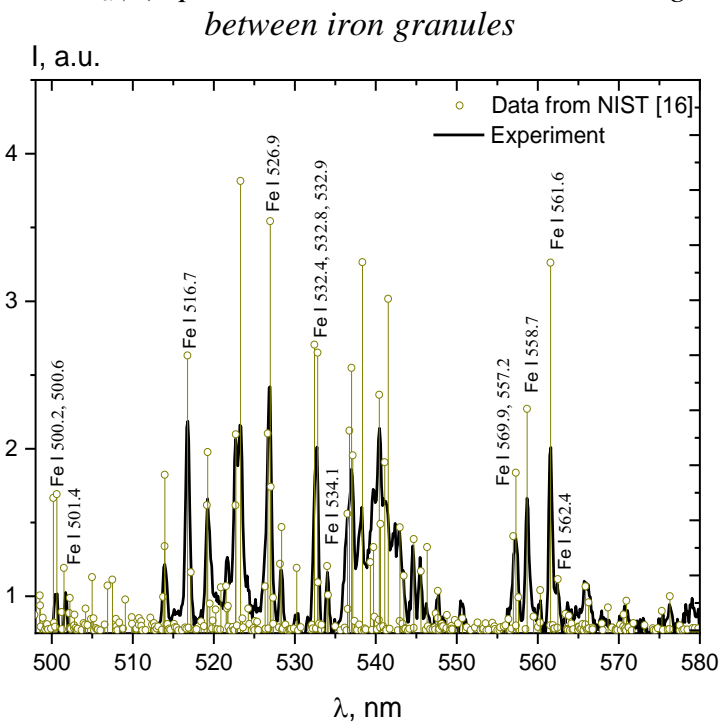

Fig. 4. Plasma emission spectrum of underwater discharge between iron granules with data from NIST [16]

These lines were used to estimate the exctitation temperature by Boltzmann plot technique. As one can see from Fig. 5, the procedure of continuum treatment during line fitting can lead to different excitation temperatures (excluding continuum (squares) $(7000 \pm 800) \mathrm{K}$ and including continuum (circles) $(6500 \pm 1200) \mathrm{K})$. 


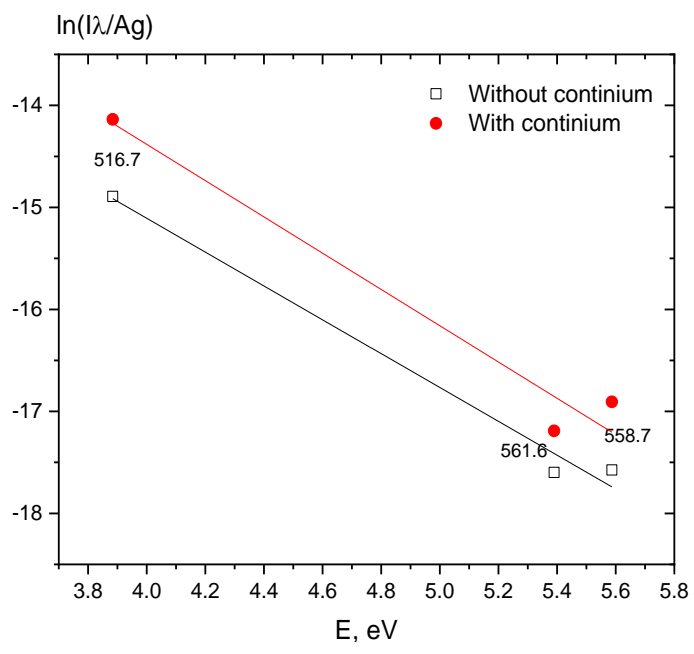

Fig. 5. Boltzmann plot on the base of enough isolated $\mathrm{Fe}$ I spectral lines fitted excluding continuum (squares) and including continuum (circles)

Several lines pairs, merged in one peak $(486 \ldots 496 \mathrm{~nm})$, were involved with the aim to clarify the values of excitation temperatures. The emission intensity of each line was separated using equation system:

$$
\left\{\begin{array}{c}
I=I_{1}+I_{2} \\
\frac{I_{1}}{I_{2}}=\frac{A_{1} g_{1} \lambda_{2}}{A_{2} g_{2} \lambda_{1}} e^{-\frac{E_{1}-E_{2}}{T}},
\end{array},\right.
$$

where I istotal intensity of merged two spectral lines, obtained by one-peak fitting; $\mathrm{I}_{1}$ and $\mathrm{I}_{2}$ are intenseties of first and second spectral lines, respectively; $A_{i}, g_{i}, \lambda_{i}$, and $E_{i}$ are transition probability, statistical weight, wavelength and energy of upper atomic level of corresponding spectral line, respectively.

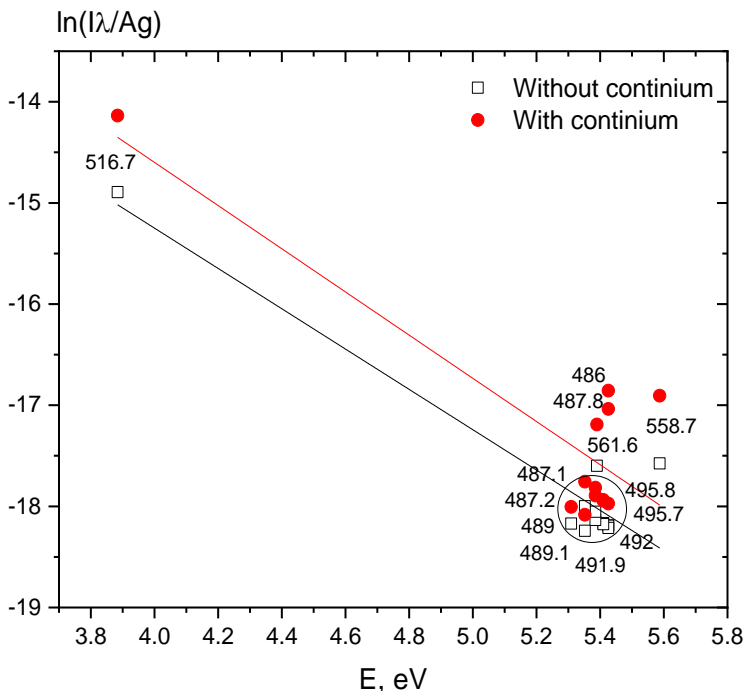

Fig. 6. Boltzmann plot on the base of enough isolated and separated Fe I spectral lines fitted excluding continuum (squares) and including continuum (circles)

The estimation of excitation temperatures with account of such lines was provide by Boltzmann plotas shown in Fig. 6. The involving of separated spectral lines to Boltzmann plot leads to decrease of the excitation temperatures (excluding continuum (squares) $(5800 \pm 600) \mathrm{K}$ and including continuum (circles) $(5400 \pm 1000) \mathrm{K}$. The behavior of population densities allows us to conclude, that the account of continuum has a negligible effect to $486 \ldots 496 \mathrm{~nm}$ (except 486 and 487.8) spectral lines but remarkable for $516.7,558.7$, and $561.6 \mathrm{~nm}$. Thus, Boltzmann plots in Fig. 6 do not give final answer on the continuum impact on excitation temperatures.

On the other hand, such divergence can be caused by the integration of various discharge emission areas with different temperatures or/and temporal changes of plasma parameters during exposing.

Simple modelling of emission spectra was performed to estimate the excitation temperatures by comparing simulated and experimental spectrum (Fig. 7). The $67 \mathrm{Fe}$ I spectral lines in $550 \ldots .570 \mathrm{~nm}$ range was used in this modelling with spectroscopic data from [16]. Each line was considered to have Gaussian profile. Excitation temperature and line width were the main parameters to obtain the best fit with experimental spectrum.

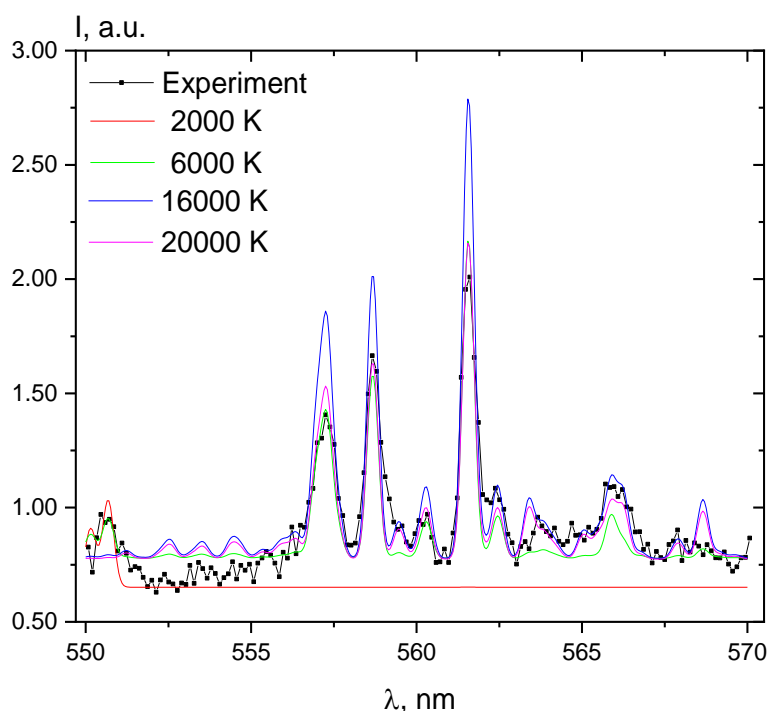

Fig. 7. Modelling and experimental emission spectra of underwater discharge plasma between iron granules

It was found that the coincidence of simulation and experiment is occurred not over the entire spectrum, but only over its narrow areas. Namely, four spectral areas of plasma emission with different temperatures are found. Specifically, the coinciding of $550 \ldots 552 \mathrm{~nm}$ experimental and modeling spectral line are characterized by $2000 \mathrm{~K}$. Spectral ranges in the vicinity of 560 and $566 \mathrm{~nm}$ are characterized by 20000 and $16000 \mathrm{~K}$, respectively. The best fit for Fe I 558.7 and $561.6 \mathrm{~nm}$ spectral lines is observed at temperature, obtained by Boltzmann plots $(\sim 6000 \mathrm{~K})$. The results of such comparison confirm the spatial or/and temporal integrated nature of emission in registered spectrum.

\section{CONCLUSIONS}

The difficulties in selection of the spectral lines of iron, as well as the approximation of their profiles were described. It was found two problems in fittings of spectral lines by Voight function. Specifically, it is the account of continuum emission and impact of spectral lines overlapping.

The excitation temperatures are determined by Boltzmann plots in manner with excluding and 
including continuum. It can be assumed that divergence between temperatures can be explained by the integration of plasma emission areas with different temperatures or/and temporal changes of plasma parameters during exposing. Therefore, the simple modelling of emission spectra was proposed to estimate the excitation temperatures. The obtained modelling results confirm the existence of various spectral ranges with different excitation temperatures on the observed emission spectrum of underwater discharge plasma between iron granules.

\section{REFERENCES}

1. N. Babaeva, M. Kushne. Streamer branching: the role of Inhomogeneities and bubbles // IEEE Trans Plasma Sci. 2008, v. 36, p. 892-893.

2. P. Bruggeman, C. Leys, Non-thermal plasmas in and in contact with liquid. Topical Review // J. Phys. D: Appl. Phys. 2009, v. 42, p. 053001.

3. J. Clements, M. Sato, R. Davis. Preliminary investigation of prebreakdown phenomena and chemical reactions using a pulsed high-voltage discharge in water // IEEE Trans. Ind. Appl. 1987, v. 23, p. 224-235.

4. T. Ternes, R. Hirsch. Occurrence and behaviour of Xray contrast media in sewage facilities and the aquatic environment // Environ. Sci. Technol. 2000, v. 34, p. 2741-2748.

5. J. Dunnick, R. Melnick, Assessment of the carcinogenic potential of chlorinated water: experimental studies of chlorine, chloramine, and trihalomethanes // J. Natl. Cancer. Inst. 1993, v. 85, p. 817-822.

6. T. Ternes, J. Stueber, N. Herrmann, D. Mcdowell, A. Ried, M. Kampmann, B. Teiser. Ozonation: a tool for removal of pharmaceuticals, contrast media and musk fragrances from wastewater // Water Res. 2003, v. 37, p. 1976-1982.

7. O.L. Li, J. Chang, Y. Guo. Pulsed. Arc Electrohydraulic Discharge characteristics and plasma parameters of sludge-water // IEEE Conference on Electrical Insulation and Dielectric Phenomena. 2009, p. 331-334

8. P. Sunka. Pulse electrical discharges in water and their applications // Phys. Plasmas. 2001, v. 8, p. 25872594.

9. H. Kiyama, T. Sakugawa, T. Namihira. Industrial applications of pulsed power technology // IEEE Trans. Dielectr. Electr. Insul. 2007, v. 14, p. 1051-1064.

10. H. Bluhm, W. Frey, H. Giese. Application of pulsed $\mathrm{HV}$ discharges to material fragmentation and recycling // IEEE Trans. Dielectr. Electr. Insul. 2000, v. 7, p. 625636.

11. Q. Chen, J. Li, Y. Li. A review of plasma-liquid interactions for nanomaterial synthesis // J. Phys. D: Appl. Phys. 2015, v. 48 (42), p. 424-450.

12. B01J 13/00 Patent of Ukraine Mother colloidal solution of metals / K. Lopatko, E. Aftandiliants, S. Kalenska, O. Tonkha. № 3845912 Jan 2009.

13. Z. Xiu, Q. Zhang, H. Puppala, V. Colvin, P. Alvarez. Negligible particle-specific antibacterial activity of silver nanoparticles // Nano Letters. 2012, v. 12 (8), p. $4271-4275$

14. T. Tmenova. Etude expérimentale de la décharge électriquepulsée dans l'eau (Thesis), Toulouse (France), 2019.

15. A. Nikiforov, C. Leys, M. Gonzalez, J. Walsh. Electron density measurement in atmospheric pressure plasma jets: Stark broadening of hydrogenated and nonhydrogenated lines // Plasma Sources Science Technology. 2015, v. 24(3), p. 034001

16. A. Kramida, Yu. Ralchenko, J. Reader and NIST ASD Team. NIST Atomic Spectra Database (ver. 5.7.1), [Online]. Available: https://physics.nist.gov/asd [2020, October 20]. National Institute of Standards and Technology, Gaithersburg, 2019.

Article received 29.10.2020

\title{
ТЕМПЕРАТУРЫ ЗАСЕЛЕНИЯ В ПЛАЗМЕ ПОДВОДНОГО РАЗРЯДА МЕЖДУ ГРАНУЛАМИ ЖЕЛЕЗА
}

\section{А. Мурманцев, А. Веклич, В. Борецкий}

\begin{abstract}
Представленная статья посвящена разработке методов оптической эмиссионной спектроскопии для диагностики плазмы подводного разряда между гранулами железа. Обсуждены трудности селекции спектральных линий железа, а также аппроксимации их профилей для определения температуры заселения. Рассмотрен метод разрешения спектральных линий с близкими длинами волн. Для оценки температур заселения в плазме подводного разряда выполнено моделирование узкого участка спектра излучения плазмы при различных температурах.
\end{abstract}

\section{ТЕМПЕРАТУРИ ЗАСЕЛЕННЯ В ПЛАЗМІ ПІДВОДНОГО РОЗРЯДУ МІЖ ГРАНУЛАМИ ЗАЛІЗА}

\section{О. Мурманцев, А. Веклич, В. Борецьький}

Представлена стаття присвячена розробці методів оптичної емісійної спектроскопії для діагностики плазми підводного розряду між гранулами заліза. Обговорено труднощі селекції спектральних ліній заліза, а також апроксимації їх профілів для визначення температури заселення. Розглянуто метод розділення спектральних ліній з близькими довжинами хвиль. Для оцінки температур заселення в плазмі підводного розряду виконано моделювання вузької ділянки спектру випромінювання плазми при різних температурах. 